\title{
Green Economy as a Vision to Sustainable Path for Achieving Real Prosperity
}

\author{
Nora Mohammed Rehan Hussien
}

\begin{abstract}
Emerging global threats to "Our Common Future" require much greater collective action, improved benefit sharing from natural resource development. This needs a new moral imperative linked to equitable outcomes, and equal claims, including the rights of future generations. We have to find a new approach to achieve sustainable development. A Green Economy is an alternative vision for growth and development; which generate growth and improvements in life in ways consistent with sustainable development. A Green Economy promotes a triple bottom line: sustaining and advancing economic, environmental and social well-being. It's focus on sustainable development, poverty reduction, low carbon, resource efficient, and socially inclusive. In a green economy, growth in income and employment should be enhancing energy and resource efficiency. It's focused on increasing GDP above all other goals. It comes with significant social, environmental and economic costs. Since the United Nations Conference on Environment and Development 1992, has focused on achieving sustainable development, economy in general and green economy in particular. The research will shed light on one of the most successful case studies in green economy (The Republic of Korea), and then propose a strategy as a flexible policy framework that provides seven principles to achieve green economy.
\end{abstract}

Index Terms-Sustainable development, green economy, growth \& development, green growth, energy efficiency.

\section{INTRODUCTION}

Twenty years after the first Rio Summit, the world continues to face a twin challenge: expanding economic opportunities for all in the context of a growing global population; and addressing environmental pressures that, if left unaddressed, could undermine our ability to seize these opportunities. Green growth is where these two challenges meet and it is about exploiting the opportunities to realize the two together.

\section{OBJECTIVES}

The main objective is Developing a green growth strategy that combines economic, environmental, social, technological, and development aspects into a comprehensive framework. This goal is achieved through a set of sub - goals which are:

- Identify the concept of green economy and its main

Manuscript received May 26, 2017, revised July 28, 2017.

Nora Mohamed Rehan Hussein is with the Head of Architecture Department, Faculty of Engineering, Ahram Canadian University, Egypt (e-mail: nora.rehan@yahoo.com). principles.

- Identify the difference between growth and development

- The relationship between sustainable development and the green economy

- Focus light on the case study of the Republic of Korea in the green economy as it is considered one of the best case studies all over the world to achieve a successful strategy to implement the green economy.

\section{PROBLEMS}

There is a conflict between the economic plans and the protection of the environment this is illustrated by urban environmental problems which are mostly urban sprawl, pollution of soil, air, traffic and transportation, noise, infrastructure and services, inadequate water supply, wastewater, solid waste, energy, loss of green and natural spaces, Lack of affordable housing, etc. [1]. All these problems are particularly serious in developing countries and countries with economic transition.

\section{Sustainability And Sustainable City}

Sustainability is the ability to sustain the quality of life which we aspire, it is often viewed as enhancing the economic, social, cultural and environmental well-being of current and future residents [2].

Sustainable city is a city that satisfies the needs of the present inhabitants without reducing the capacity of the future generation to satisfy their needs....In the livable city both social and physical elements must collaborate for the well-being and progress of the community, and of the individual persons as members of the community [3].

\section{ECONOMY}

Economics means the study of the way in which mankind organizes itself to tackle the basic problems of scarcity. All societies have more wants than resources. Hence, a system must be devised to allocate these resources between competing ends. Thus, Economics is the social science that studies economic activities [4].

Adam Smith's Definition: Adam Smith considered being the founding father of modern Economics, defined Economics as the study of the nature and causes of nations' wealth or simply as the study of wealth.

Lionel Robbins' Definition: "Economics is a science which studies human behavior as a relationship between ends and scarce means which have alternative uses" [5]. 


\section{GROWTH}

This is reasonably unambiguous; it is the change in national income over time, usually measured over one year. National income is the amount produced by a country in one year [6].

\section{THE GREEN ECONOMY}

The green economy is the aggregate of all activity operating with the primary intention of minimizing all forms of environmental impact. As the green economy continues to evolve, it is evident that skills gaps are emerging. Research indicated that the application of increased specialized skills will be needed to support green economic activity in: Wind and solar energy, Battery technology and power electronics, Sustainability, management and energy efficiency, Environmental finance and emissions trading. [7] The green economy is a key to countries' abilities to achieve economic growth, create green jobs, and protect the environment." [8] green growth tools and indicators can help expand economic growth and job creation through sustainable use of natural resources, efficiencies in the use of energy, and valuation of ecosystem services. Ministers noted that innovation, supported by a strong intellectual property rights system.

\section{THE GREEN GROWTH}

Green growth means fostering economic growth and development while ensuring that natural assets continue to provide the resources and environmental services on which our well-being relies We need green growth because risks to development are rising as growth continues to erode natural capital. If left unchecked, this would mean increased water scarcity, worsening resource bottlenecks, greater pollution, climate change, and unrecoverable biodiversity loss. To do this it must catalyze investment and innovation which will underpin sustained growth and give rise to new economic opportunities.

\section{GReEn ECONOMY AND Sustainable DEVElopMENT}

Sustainable development provides an important context for green economy. Green economy is not a replacement for sustainable development but rather should be considered a subset of it. Rather, it provides a practical and flexible approach for achieving concrete, measurable progress across its economic and environmental pillars, while taking full account of the social consequences of greening the growth dynamic of economies [9]. The focus of green economy strategies is ensuring that natural assets can deliver their full economic potential on a sustainable basis. That potential includes the provision of critical life support services - clean air and water, and the resilient biodiversity needed to support food production and human health [10].

\section{Case Study}

The Republic of Korea case study is considered one of the most successful case studies in green economy all over the world. Korea is the first country in the Organization for Economic Cooperation and Development OECD to have produced an explicit and comprehensive green growth strategy [11]. There is international recognition of the Republic of Korea as a green force. It has been widely recognized as the only country so far to have operationalized green growth on a national scale by setting ambitious targets and implementing action plans. Looking to the future, unlocking the short- and long-term economic, social, and environmental benefits of green growth and demonstrating tangible results on the ground remain the critical tests for the ROK's low-carbon green growth model. If this strategy succeeds in reaping positive results at home, it could create strong ripple effects beyond the ROK's borders [12].

\section{A. Green Growth in Action, Korea, the Goals}

The National Strategy for Green Growth and the Five-Year Plan (2009-2013) of Korea provide a comprehensive policy framework for green growth. The Strategy aims to:

- Advancement of green growth as a national agenda.

- Building a solid foundation for the nation's climate change mitigation policy.

- The potential of green technology to serve as a new growth engine.

- The conceptual limitations of low-carbon green growth by contributing international efforts to fight climate change by realizing a framework act on low carbon green growth was enacted in 2010 .

- Promote eco-friendly new growth engines.

- Enhance peoples' quality of life.

\section{B. Korea's Green Growth and the Green Economy}

Green Growth strategy comprises two key sectors:

7-2-1- Low-carbonization - reduction of greenhouse gas and environmental pollution for defensive green growth

7-2-2- Green industrialization - generation of new growth power and jobs for offensive green growth and that is through:

- Promotion of Green Economy and Industry

- Measures for Climate Change and Energy

- Construction of Sustainable Territory and Environment [13].

\section{Korea's Strategic Pillars}

There is a set of pillars on which the green economy strategy in Korea is based, as shown in the following table:

\section{Deduction: The GreEn ECONOMY STRATEGY}

The research proposes a strategy as a flexible policy framework that can be tailored to different country circumstances and stages of development which provides seven recommendations and measurement tools to support countries' efforts to achieve economic growth and development, while at the same time ensure that natural assets continue to provide the ecosystem services on which our well-being relies. This strategy provides a practical framework for governments in developed and developing countries to seize opportunities that arise when the economy and the environment work together. These seven 
recommendations of strategic pillar are: Green The Natural Asset Base, Socio-Economic Context and industrialization, Improve the quality of life, Economic Characteristics of Growth, Green Technology. opportunities and policy responses, urban opportunities,

TABLE I: KOREA’s STRATEGIC PILLARS

\begin{tabular}{|c|c|c|c|}
\hline Strategic pillar & Strategic axis & Quantitative & objective Project \\
\hline $\begin{array}{l}\text { 1-The environmental } \\
\text { and resource } \\
\text { productivity of the } \\
\text { economy }\end{array}$ & $\begin{array}{l}\text { The "greening "of existing } \\
\text { industries and the promotion } \\
\text { of green industries }\end{array}$ & $\begin{array}{l}\text { - Increase share of recycled waste, } \\
\text { green exports, green industrial zones. }\end{array}$ & $\begin{array}{l}\text { Promotion of re-using waste and } \\
\text { Support for greening of traditional } \\
\text { strategic industries }\end{array}$ \\
\hline $\begin{array}{l}\text { 2-Improve the quality } \\
\text { of life }\end{array}$ & $\begin{array}{l}\text { Advancement of industrial } \\
\text { structure to increase services }\end{array}$ & - Increase value of exports. & $\begin{array}{l}\text { - Investments in high value-added } \\
\text { industries: health, education, } \\
\text { telecommunication. }\end{array}$ \\
\hline $\begin{array}{l}\text { 3-Economic } \\
\text { opportunities and } \\
\text { policy responses }\end{array}$ & $\begin{array}{l}\text { Engineering is a structural } \\
\text { basis for the green economy. } \\
\text { - Reduce by } 50 \% \text { of } \\
\text { households with insufficient } \\
\text { access to energy } \\
\text { - Create } 500 \text { green, socially } \\
\text { responsible companies. }\end{array}$ & $\begin{array}{l}\text { - Increase secured public loans for } \\
\text { green technologies. } \\
\text { - Reduce by } 50 \% \text { the number of } \\
\text { households with insufficient access to } \\
\text { energy } \\
\text { - Create } 500 \text { green, socially } \\
\text { responsible companies. }\end{array}$ & $\begin{array}{l}\text { Implementation of a coherent } \\
\text { environmental tax systems to correct } \\
\text { price signals } \\
\text { - Labor market training programmers } \\
\text { for workers transitioning to green } \\
\text { jobs }\end{array}$ \\
\hline 4- Urban opportunities & $\begin{array}{l}\text { Greening land and water, } \\
\text { and building green transport } \\
\text { infrastructure - }\end{array}$ & $\begin{array}{l}\text { Greening land and } \\
\text { Expand nature reserves. } \\
\text { - Increase share of rail ridership. } \\
\text { - Increase share of cycling in urban } \\
\text { passenger transport. }\end{array}$ & $\begin{array}{l}\text { - Creation of carbon } \\
\text { Neutral cities. } \\
\text { - Construction of } 1.5 \text { million social } \\
\text { housing units and } 2 \text { million green } \\
\text { housing units. } \\
\text { - Implementation of an evaluation } \\
\text { system for green buildings } \\
\text { - Construction of new railway lines } \\
\text { and of } 3000 \mathrm{~km} \text { of bike lanes }\end{array}$ \\
\hline $\begin{array}{l}\text { 5-The natural asset } \\
\text { base }\end{array}$ & $\begin{array}{l}\text { Bringing the green } \\
\text { revolution to daily lives }\end{array}$ & $\begin{array}{l}\text { - Increase number of green } \\
\text { households. } \\
\text { - Increase number of goods for which } \\
\text { the carbon footprint is awarded. } \\
\text { - Increase public consumption of } \\
\text { green products. } \\
\text { - Construct } 500 \text { ecological cities by } \\
2020\end{array}$ & $\begin{array}{l}\text {-Public information campaigns to } \\
\text { educate consumers about green } \\
\text { consumption behavior. } \\
\text { - Development of ecological tourism } \\
\text { - Support for voluntary participation } \\
\text { in green programmers. }\end{array}$ \\
\hline $\begin{array}{l}\text { 6-Socio-economic } \\
\text { context and } \\
\text { characteristics of } \\
\text { growth }\end{array}$ & $\begin{array}{l}\text { Becoming a role-model for } \\
\text { the international community } \\
\text { as a green growth leader }\end{array}$ & $\begin{array}{l}\text { - Increase share of green projects in } \\
\text { foreign economic aid. }\end{array}$ & $\begin{array}{l}\text { Active participation in upcoming } \\
\text { international negotiations on global } \\
\text { climate change }\end{array}$ \\
\hline
\end{tabular}

Source: The Presidential Committee on Green Growth (2009).

TABLE II: THE GREEN ECONOMY STRATEGY

\begin{tabular}{|c|c|c|c|c|c|c|c|c|}
\hline Quantitative & $\begin{array}{l}\text { - Increase } \\
\text { share of } \\
\text { recycled } \\
\text { waste, } \\
\text { green } \\
\text { exports, } \\
\text { green } \\
\text { industrial } \\
\text { zones. }\end{array}$ & $\begin{array}{r}\text {-Solar power } \\
\text { - Clean coal } \\
\text { technologies } \\
\text {-Wind } \\
\text { power }\end{array}$ & $\begin{array}{l}\text { - Boiler } \\
\text { improvement } \\
\text { - Waste } \\
\text { Management } \\
\text { Promote } \\
\text { source } \\
\text { reduction, } \\
\text { recycle and } \\
\text { reuse. }\end{array}$ & $\begin{array}{l}\text { - Investments in high } \\
\text { value-added } \\
\text { industries: health, } \\
\text { education, } \\
\text { telecommunication. }\end{array}$ & $\begin{array}{l}\text { - Reduce the } \\
\text { number of } \\
\text { households } \\
\text { with } \\
\text { insufficient } \\
\text { access to } \\
\text { energy. } \\
\text { - Create } \\
\text { greener, } \\
\text { socially } \\
\text { responsible } \\
\text { companies. }\end{array}$ & $\begin{array}{l}\text { - } \\
\text { Construction } \\
\text { social \& } \\
\text { green } \\
\text { housing } \\
\text { units. }\end{array}$ & $\begin{array}{l}\text {-Greening } \\
\text { land and } \\
\text { Expand } \\
\text { nature } \\
\text { reserves. }\end{array}$ & $\begin{array}{l}\text {-Improvement } \\
\text { of urban mass } \\
\text { transport } \\
\text { systems } \\
\text { - } \\
\text { Fuel-efficiency } \\
\text { improvements } \\
\text { - Increase share } \\
\text { of rail } \\
\text { ridership. } \\
\text { - Increase share } \\
\text { of cycling in } \\
\text { urban } \\
\text { passenger } \\
\text { transport. }\end{array}$ \\
\hline Strategic axis & $\begin{array}{l}\text { "greening } \\
\text { "of } \\
\text { existing } \\
\text { industries } \\
\text { and the } \\
\text { promotion } \\
\text { of green } \\
\text { industries }\end{array}$ & -Energy & -Industry & $\begin{array}{l}\text { Advancement of } \\
\text { industrial structure } \\
\text { to increase services }\end{array}$ & $\begin{array}{l}\text {-Engineering } \\
\text { is a structural } \\
\text { basis for the } \\
\text { green } \\
\text { economy. }\end{array}$ & $\begin{array}{l}\text { - Creation of } \\
\text { carbon } \\
\text { Neutral cities }\end{array}$ & $\begin{array}{l}\text {-Greening } \\
\text { land and } \\
\text { water, and } \\
\text { building }\end{array}$ & $\begin{array}{l}\text {-Green } \\
\text { transport } \\
\text { infrastructure }\end{array}$ \\
\hline Strategic pillar & \multicolumn{3}{|c|}{$\begin{array}{c}1- \\
\text { Green industrialization }\end{array}$} & $\begin{array}{l}\text { 2-Improve the } \\
\text { quality of life }\end{array}$ & $\begin{array}{l}\text { 3-Economic } \\
\text { opportunities } \\
\text { and policy } \\
\text { responses }\end{array}$ & \multicolumn{3}{|c|}{$\begin{array}{c}4- \\
\text { Urban opportunities }\end{array}$} \\
\hline
\end{tabular}


TABLE III: THE GREEN ECONOMY STRATEGY

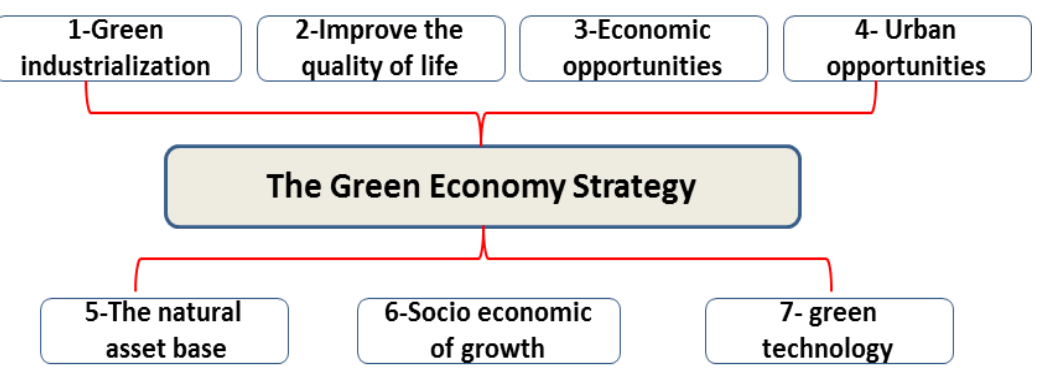

\begin{tabular}{|c|c|c|c|}
\hline $\begin{array}{l}\text { Strategic } \\
\text { pillar }\end{array}$ & $\begin{array}{c}\text { 5- } \\
\text { The Natural Asset Base }\end{array}$ & $\begin{array}{c}\text { 6- } \\
\text { Socio-Economic Context } \\
\text { And Characteristics Of } \\
\text { Growth }\end{array}$ & $\begin{array}{c}7- \\
\text { Green Technology }\end{array}$ \\
\hline $\begin{array}{l}\text { Strategic } \\
\text { axis }\end{array}$ & $\begin{array}{l}\text { Bringing the green revolution to } \\
\text { daily lives }\end{array}$ & $\begin{array}{l}\text { Becoming a role-model for } \\
\text { the international community } \\
\text { as a green growth leader }\end{array}$ & $\begin{array}{l}\text {-Green Technologies in : } \\
\text {-Industrial Sector } \\
\text { - Agricultural Sector } \\
\text { - Information and Communications } \\
\text { Technology Sector. } \\
\text { - Building Sector. }\end{array}$ \\
\hline Quantitative & $\begin{array}{l}\text { - Increase number of green } \\
\text { households. } \\
\text { - Increase number of goods for } \\
\text { which the carbon footprint is } \\
\text { awarded. } \\
\text { - Increase public consumption of } \\
\text { green products. } \\
\text { - Construct more ecological cities } \\
\text {-Development of ecological } \\
\text { tourism } \\
\text { - Support for voluntary } \\
\text { participation in green programmers. }\end{array}$ & $\begin{array}{l}\text { - Educate consumers about } \\
\text { green consumption behavior. } \\
\text { - Increase share of green } \\
\text { projects in foreign economic } \\
\text { aid. } \\
\text {-Active participation in } \\
\text { upcoming international } \\
\text { negotiations on global } \\
\text { climate change }\end{array}$ & $\begin{array}{l}\text { - Innovation and comprise a set of } \\
\text { products, services and systems that are } \\
\text { continuously evolving. } \\
\text { - Increase secured public loans for green } \\
\text { technologies. } \\
\text { - Minimize damage to the environment. } \\
\text { - Promote a healthy and improved } \\
\text { environment for all life. } \\
\text { - Conserve the use of energy and natural } \\
\text { resources. } \\
\text { - Promote the use of renewable resources. }\end{array}$ \\
\hline
\end{tabular}

\section{RECOMMENDATIONS}

Strategies for greener growth need to be tailored to fit specific country circumstances. They will need to carefully consider how to manage any potential trade-offs and best exploit the synergies between green growth and poverty reduction. The latter include, for example, bringing more efficient infrastructure to people (e.g. in energy, water and transport), tackling poor health associated with environmental degradation and introducing efficient technologies that can reduce costs and increase productivity, while easing environmental pressure. Given the centrality of natural assets in low-income countries, green growth policies can reduce vulnerability to environmental risks and increase the livelihood security of the poor.

\section{CONCLUSION}

Creating a global architecture that is conducive to green growth will require enhanced international co-operation. Strengthening arrangements for managing global public goods, especially biodiversity and climate, hold the key to addressing co-ordination and incentive problems. The research aims to identify the policy mixes and measurement tools that countries in different situations can adopt to implement green growth in a way that contributes to poverty eradication, employment opportunities, and a strong and sustainable economy.
[1] Ksenija, Environmental Problems of Modern Cities, December 19 2016.

[2] V. Timmer and N.-K. Seymoar, "The world urban Forum ,Vancouver working group discussion paper," the International Centre for Sustainable Cities, 2006

[3] E. Salzano, "Seven aims for the livable city," 1997.

[4] Meaning and Definitions of Economics.

[5] L. Robbins, "Essays on the nature and significance of the economic science," 1932.

[6] K. Bucknall, "The differences between "economic growth" and "economic development"," 2013

[7] Defining the Green Economy LABOUR MARKET RESEARCH STUDY, 2010.

[8] Towards Green Growth, OECD Better Polices For Better Lives, May 25, 2011.

[9] What Is Green Growth and How Can It Help Deliver Sustainable Development?

[10] E. B. Barbier, The Green Economy Post Rio+20, vol. 338, issue 6109 , pp. $887-888$.

[11] L. Kamal-Chaoui et al., "The Implementation of the Korean green growth strategy in urban areas," OECD Publishing, 2011,

[12] Korea's Green Growth Experience: Process, Outcomes and Lessons Learned, Global Green Growth Institute, 2015.

[13] M. Cho, Dankook University, Is the Green Economy Secure in Korea? Dissecting Korea's Green Growth Strategy, Seoul, Korea, October 18th-21st, 2010

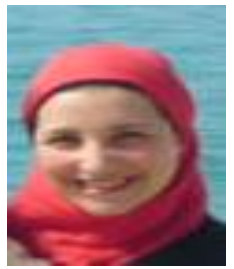

Nora Mohammed Rehan Hussein is assistant professor, the head of Architecture Department, Faculty of Engineering, Ahram Canadian University. She got the bachelor of architecture engineering, Cairo University, Cairo, Egypt, 2000-2001; She got the master degree of sciences in architecture (MSc.), Faculty of Engineering, Cairo University Cairo, Egypt, 2002-2004. " Towards a local agenda for sustainability". And she got the doctorate of philosophy in architecture from Faculty of Engineering, Cairo University, Cairo, Egypt. 